\title{
I mpact of solid waste disposal on ground water quality near Gazipur dumping site, Delhi, India
}

\section{Nitin K amboj* and M ohrana Choudhary}

Department of Zoology and Environmental Science, Gurukula Kangri University, Haridwar -249404 (Uttarakhand), INDIA

*Corresponding author. E-mail: kambojgurukul@gmail.com

Received: February 28, 2013; Revised received: J une 17, 2013; Accepted: J uly 20, 2013

Abstract: The present study was carried out to study the impact of domestic wastes disposal on ground water quality at Delhi, India. Ground water is one of the major sources of drinking water in arid and semi-arid regions. Ground water quality data and its distributions are important for the purpose of planning and management. The samples of ground water were collected and analyzed for various physico-chemical parameters viz. conductivity, total dissolved solids (TDS), alkalinity, total hardness, calcium, magnesium, chloride, sulphate, nitrate, phosphate, fluoride, sodium and potassium. Among these parameters, TDS were found higher 1400, 1068, 1524, 1656, 840, 1106, 1540, 1330, 1900, 1960, 1914, $2061 \mathrm{mg} / \mathrm{l}$ at all the Ga1,Ga2, Ga3, Ga4, Ga5, Ga6, Ga7, Ga8, Ga9, Ga10, Ga11, Ga12, Ga13, Ga14, Ga15, Ga16 sampling sites respectively. TDS were observed beyond the desirable limits of BIS at all the sampling sites. Maximum value of TDS $(2061 \mathrm{mg} / \mathrm{l})$ was found at the sampling site Ga12 while the minimum value of TDS (1061 mg/l) was found at the sampling site Ga2. Maximum value of chloride (560 mg/l) was found at sampling site Ga4, while the minimum value of chloride $(60 \mathrm{mg} / \mathrm{l})$ was found at sampling site $\mathrm{Ga} 5$ and rest all other parameters were found within permissible limit. The present study concluded that the chloride and TDS in water samples were above to the desirable limit and below to the permissible limit of BIS and rest all other parameters were within desirable limit.

Keywords: Domestic waste, Ground water quality, Landfill, Gazipur dumping site

\section{INTRODUCTION}

Delhi is the capital of India and located on the bank of Yamuna River. It lies between $28^{\circ} 38^{\prime} \mathrm{N}$ latitudes and $77^{\circ}$ $12^{\prime}$ E longitudes with the total geographical area $1,483.01$ sq $\mathrm{km}$. In most of the developing countries, municipal solid waste (MSW) disposal has been a chronic problem, particularly in areas with high population density, high production of refuse, and scarcity of land adequate for landfills (Sadek and El-Fadel, 2000). In India, ground water is the main source of drinking water and also indispensable source for living beings. The ground water quality problem has become acute nowadays (Kumar and Sinha, 2010). In urban areas of the country, uncontrolled growth of population has left several cities deficient in infrastructural services viz., water supply, sewerage and solid waste management. To evolve strategies for the improvement of water supply and sanitation, various methods have been adopted (Kumar and Gaikwad, 2004). During the last two decades, groundwater quality has emerged as one of the most important environmental issues confronting much of the world's population (Moench, 1996). Due to lack of efficient solid waste management system and improper dumping of MSW as open landfills, the ground water and surface water in
Delhi is found to be contaminated in various places (Rajkumar et al., 2010). Solid waste includes all the discarded solid materials from commercial, municipal, industrial, and agricultural activities. Land filling is the preferred method of municipal solid waste (MSW) disposal due to its favorable economics. However, poorly designed landfills can create contamination of groundwater, soil, and air. The most commonly reported danger to the human health from these landfills is from the use of groundwater that has been contaminated by leachate (Rajkumar et al., 2010). As water percolates through the landfill, contaminants are leached from the solid waste. Leachate is produced when moisture enters to refuse in a landfill, extracts contaminants into the liquid phase, and produces moisture content sufficiently high to initiate liquid flow. Leachate is generated in a landfill as a consequence of the contact of water with solid waste. Leachate may contain dissolved or suspended material associated with wastes disposed off in the landfill, as well as many byproducts of chemical and biological reactions. Strength of leachate from MSW landfills varies with the progress of biological activity occurring in landfill. Leachate from young landfill has both high dissolved solids, as well as high concentration of organic matter. Leachate tended to migrate in surrounding soil ISSN : 0974-9411 (Print), 2231-5209 (Online) All Rights Reserved @ Applied and Natural Science Foundation www.ansfoundation.org 
may result in contamination of underlying soil and groundwater (Jhamnani and Singh, 2009). The rate and characteristics of leachate produced depends on many factors such as solid waste composition, particle size, degree of compaction, hydrology of site, age of landfill, moisture and temperature conditions, and available oxygen. During the course of stabilization of landfilled wastes, non-conservative constituents of leachate (primarily organic in nature) tend to decompose and stabilize with time, whereas conservative constituents will remain long after waste stabilization occurs. Conservative constituents include various heavy metals, chloride, and sulfide. Metals often are precipitated within the landfill and are infrequently found at high concentrations in leachate, with the exception of iron. The problem of ground water pollution in several parts of the country has become so acute that unless urgent steps for detailed identification and abatement are taken, extensive ground water resources may be damaged (Jain et al., 2004). An MSW management scheme is a complex system of social, economic, legal, political, environmental, technical and operational nature. Rational decisions cannot be taken and applied unless a complete and accurate picture of the whole MSW problem is available and a hierarchical classification of the system components can be produced (Hadjibiros et al., 2011).Keeping above in view the present investigation was conducted to study the impact of solid waste disposal on ground water quality near Gazipur dumping site, Delhi, India.

\section{MATERIALS AND METHODS}

Study area: The present study was conducted around Gazipur municipal dumping site at Delhi. The selected experimental area of Gazipur landfill site started in the year 1984 and still in use. It spreads over an area of approximately $3 \times 105 \mathrm{M}^{2}$ and situated near National Highway 24. The experimental site is located at latitudes $28^{\circ} 35^{\prime} \mathrm{N}$, longitude $77^{\circ} 12^{\prime} \mathrm{E}$ and at an altitude of $218 \mathrm{~m}$ above the mean sea level (Fig.1). The climatic regime of Delhi belongs to the semi arid type and characterized by extreme dry conditions associated with hot summers and cold winters. The temperature ranges between $18.7^{\circ} \mathrm{C}$ (mean minimum) and $40.3^{\circ} \mathrm{C}$ (mean maximum). It also experiences heavy rains primarily during the periods of monsoon with an average rainfall of 714.6 mm (Aufleger and Mett, 2011). The groundwater level in Delhi city varies between 15 to 20 meters in depth (Aufleger and Mett, 2011). On an average, 2200 metric ton/day of waste is dumped and the waste fill height varies from $12 \mathrm{~m}$ to $20 \mathrm{~m}$.

It is located at the close proximity of Hindon Canal. Delhi generates 6,000 metric tonnes of solid waste every day which is likely to increase to 18,000 metric tonnes per year by 2021 (Jhamnani and Singh, 2009). The generation rate is about $500 \mathrm{gm}$ per person per day, which is almost 5 times than the national average. The waste dumped at this site includes domestic waste, e.g. kitchen waste; paper, plastic, glass, cardboard, cloths. Construction and demolition waste consisting of sand, bricks and concrete block are also dumped. Further waste from the adjacent poultry market, fish market, slaughterhouse, dairy farm and non-infectious hospital waste is also dumped. The site is non-engineered low lying open dump, looks like a huge heap of waste up to a height of 12-20 m. Trucks from different parts of the city collect and bring waste to this site and dump the waste in irregular fashion. The main waste generated in Delhi is from the markets of agricultural products, retail and commercial markets, hospital and nursing homes, slaughter houses, industries and construction and demolition activities (Jhamnani and Singh, 2009).

The ground water samples were collected from different 16 sampling sites randomly distributed near Gazipur dumping site, Delhi, India. GPS co-ordinates of each sampling site were mentioned in table 1 .

Collection of samples and their analysis: The water samples were collected from various sampling sites in plastic containers and sampling bottles. All samples were brought to the laboratory and then analyzed for various physico-chemical parameters viz. conductivity, TDS, alkalinity, total hardness, calcium, magnesium, chloride, sulphate, nitrate, phosphate, fluoride, sodium and potassium by following standard methods cited in APHA (1998).

\section{RESULTS AND DISCUSSION}

The average \pm SD of various ground water quality parameters are shown in Table 2.

The present study indicated that the $\mathrm{pH}$ of different areas around dumping sites was ranged $6.42-7.76$, which were within the desirable limit of BIS (Table 2). Highest value of $\mathrm{pH}$ was found at the sampling site Ga14, while the minimum value of $\mathrm{pH}$ was found at the sampling site Ga13. Jameel (2002) observed $\mathrm{pH}$ to assess the alkaline nature of drinking water in Tiruchirapalli (Tamilnadu). The conductivity around the study site of Gazipur was found to be in range between of $1220 \mu \mathrm{mhos} / \mathrm{cm}-2945$ $\mu$ mhos $/ \mathrm{cm}$. Highest value of conductivity (2945) was found at the sampling site $\mathrm{Ga} 12$ while the minimum value (1220) was recorded at the site Ga5. Total dissolve solids (TDS) refers to matter suspended or dissolved in water or waste water with high content is inferior and may be polluted. In the present study, TDS of Gazipur area ranged from $840 \mathrm{mg} / \mathrm{l}$ to $2061 \mathrm{mg} / \mathrm{l}$. Highest value of TDS (2061 $\mathrm{mg} / \mathrm{l}$ ) was found at the sampling site $\mathrm{Ga} 12$, while the minimum value of TDS $(840 \mathrm{mg} / \mathrm{l})$ was found at the sampling site $\mathrm{Ga} 5$ and were above the desirable limit (500 


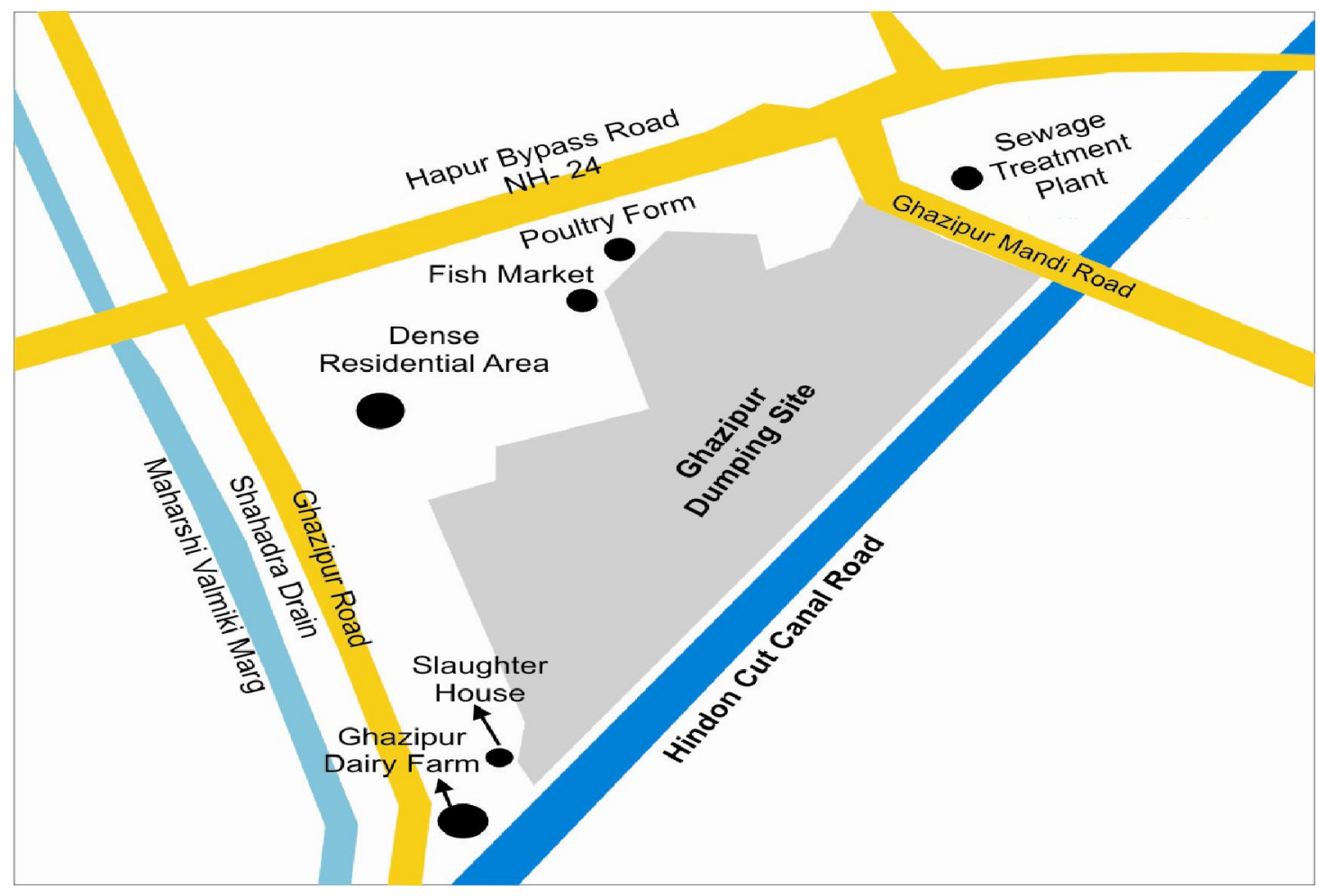

Fig. 1. Showing the study areas ( ) of Gazipur dumping site, D elhi.

$\mathrm{mg} / \mathrm{l}$ ) of BIS, which may be due to higher concentration of dissolved solids in water that causes adverse effect in taste. The very high EC and TDS observed in the groundwater suggest a downward transfer of leachate into groundwater as reported earlier by Mor et al. (2006) and Longe and Enekwechi (2007). Alewunmi et al. (2009) recorded the TDS value of $2000 \mathrm{mg} / \mathrm{l}$ in surface water near dumping area in Ondo state, in the western part of Nigeria. Jameel (2002) also observed total dissolved solid concentration between $723 \mathrm{mg} / \mathrm{l}$ to $2918 \mathrm{mg} / \mathrm{l}$ in drinking water of Tiruchirapalli (Tamil Nadu). High concentrations of TDS decrease the palatability of water and may also cause gastro-intestinal irritation in humans and laxative effects particularly upon transits (WHO, 1997). The alkalinity of water samples around Gazipur municipal dumping sites ranged from $164 \mathrm{mg} / \mathrm{l}-512 \mathrm{mg} / \mathrm{l}$. The maximum value of alkalinity $(512 \mathrm{mg} / \mathrm{l})$ was found at the sampling site Ga10 while the minimum value of alkalinity $(164 \mathrm{mg} / \mathrm{l})$ was found at the sampling site Ga8. Pandey et al. (2012) studies on physicochemical analysis of ground water near municipal solid waste dumping sites in Jabalpur reveals that the total alkalinity was found to be in the range of $76 \mathrm{mg} / \mathrm{l}$ to $198 \mathrm{mg} / \mathrm{l}$ in ground water samples which were caused mainly due to $\mathrm{OH}, \mathrm{CO} 3$ and $\mathrm{HCO} 3$ ions. In the present study, the total hardness was found in range of $360 \mathrm{mg} / \mathrm{l}-835 \mathrm{mg} / \mathrm{l}$. Highest value of hardness $(835 \mathrm{mg} / \mathrm{l})$ was recorded at the sampling site Ga12, while the minimum value $(360 \mathrm{mg} / \mathrm{l})$ was recorded at the sampling site Ga6 (Table 2). Mor et al. (2006) carried out a study on leachate characterization and assessment of groundwater pollution near municipal solid waste landfill site and observed that total hardness present in ground water in the vicinity of landfill site was in the range of $296 \mathrm{mg} / \mathrm{l}$ to $1388 \mathrm{mg} / \mathrm{l}$. Shiddamallayya and Pratima (2008) carried out a study on physico-chemical parameters of tank water in Bhalki town of Bidar of various parameters like $\mathrm{pH}$, magnesium, chloride, nitrate, sulphate and hardness of water and find out the great increase in all the parameters due to the various activities of urban areas.

During the course of study, calcium hardness was recorded as minimum $(90 \mathrm{mg} / \mathrm{l})$ at $\mathrm{Ga} 8$ to maximum as (367 $\mathrm{mg} / \mathrm{l}$ ) at Ga1. Except Ga1, other study sites have calcium hardness concentration well below to the desirable limit $(300 \mathrm{mg} / \mathrm{l})$ of BIS. In the study, magnesium hardness was also analyzed and observed in the range of $202 \mathrm{mg} / \mathrm{l}$ (minimum) at $\mathrm{Ga} 5$ to $660 \mathrm{mg} / \mathrm{l}$ (maximum) at Ga12. Only Ga12 has highest concentration of magnesium hardness even more than permissible limit of BIS (600 mg/l). Pandey et al. (2012) also found calcium and magnesium hardness in the groundwater samples. The value of calcium was found from $31 \mathrm{mg} / \mathrm{l}$ to $151 \mathrm{mg} / \mathrm{l}$ below the permissible limit of $200 \mathrm{mg} / \mathrm{l}$ of BIS in the study area. The maximum concentration was recorded at $\mathrm{Ga} 12$ while, minimum at Ga13. As far as limit of WHO for calcium concentrations is concerned, Ga1, Ga3, Ga4, Ga9, Ga11 and Ga12 had higher concentrations than permissible limit of $75 \mathrm{mg} / \mathrm{l}$. Similarly, magnesium values were found in the range of as minimum $(67 \mathrm{mg} / \mathrm{l})$ at $\mathrm{Ga} 8$ to $(155 \mathrm{mg} / \mathrm{l})$ as maximum at Ga13. All study sites had greater magnesium values than permissible limit $(50 \mathrm{mg} / \mathrm{l})$ of BIS and WHO both. Sabahi 
Table 1. Details of sampling sites near Gazipur Dumping site, Delhi.

\begin{tabular}{|c|c|c|c|c|c|}
\hline $\begin{array}{l}\text { Sampling } \\
\text { site }\end{array}$ & L ocation & L atitude & Longitude & Sour ce of water & Depth (m) \\
\hline Ga 1 & Gazipur Dairy Farm & $28^{\circ} 37^{\prime} 30^{\prime \prime} \mathrm{N}$ & $77^{\circ} 19^{\prime} 30^{\prime \prime} \mathrm{E}$ & Borewell & $150 \mathrm{M}$ \\
\hline Ga 2 & Gazipur Dairy Farm & $28^{0} 37^{\prime} 32^{\prime \prime} \mathrm{N}$ & $77^{\circ} 19^{\prime} 33^{\prime \prime} \mathrm{E}$ & Borewell & $150 \mathrm{M}$ \\
\hline Ga 3 & Gazipur Dairy & $28^{\circ} 37^{\prime} 33^{\prime \prime} \mathrm{N}$ & $77^{\circ} 19^{\prime} 33^{\prime \prime} \mathrm{E}$ & Borewell & $150 \mathrm{M}$ \\
\hline $\mathrm{Ga} 4$ & Farm & $28^{\circ} 37^{\prime} 38^{\prime \prime} \mathrm{N}$ & $77^{\circ} 19^{\prime} 37^{\prime \prime} \mathrm{E}$ & Borewell & $150 \mathrm{M}$ \\
\hline Ga 5 & Gazipur Dairy & $28^{\circ} 37^{\prime} 39^{\prime \prime} \mathrm{N}$ & $77^{\circ} 19^{\prime} 40^{\prime \prime} \mathrm{E}$ & Borewell & $150 \mathrm{M}$ \\
\hline Ga 6 & Farm & $28^{\circ} 37^{\prime} 37^{\prime \prime} \mathrm{N}$ & $77^{\circ} 19^{\prime} 47^{\prime \prime} \mathrm{E}$ & Borewell & $150 \mathrm{M}$ \\
\hline Ga 7 & Gazipur Dairy & $28^{\circ} 37^{\prime} 09^{\prime \prime} \mathrm{N}$ & $77^{\circ} 19^{\prime} 16^{\prime \prime} \mathrm{E}$ & Borewell & $150 \mathrm{M}$ \\
\hline Ga 8 & Farm & $28^{0} 37^{\prime} 16^{\prime \prime} \mathrm{N}$ & $77^{\circ} 19^{\prime} 28^{\prime \prime} \mathrm{E}$ & Bor ewell & $150 \mathrm{M}$ \\
\hline Ga 9 & Gazipur Dairy & $28^{0} 37^{\prime} 35^{\prime \prime} \mathrm{N}$ & $77^{\circ} 19^{\prime} 49^{\prime \prime} \mathrm{E}$ & Borewell & $150 \mathrm{M}$ \\
\hline Ga 10 & Farm & $28^{\circ} 37^{\prime} 38^{\prime \prime} \mathrm{N}$ & $77^{\circ} 19^{\prime} 49^{\prime \prime} \mathrm{E}$ & Borewell & $150 \mathrm{M}$ \\
\hline Ga 11 & Gazipur Dairy & $28^{\circ} 37^{\prime} 35^{\prime \prime} \mathrm{N}$ & $77^{\circ} 19^{\prime} 52^{\prime \prime} \mathrm{E}$ & Borewell & $150 \mathrm{M}$ \\
\hline Ga 12 & In slaughter House & $28^{\circ} 37^{\prime} 14^{\prime \prime} \mathrm{N}$ & $77^{\circ} 19^{\prime} 30^{\prime \prime} \mathrm{E}$ & Bor ewell & $150 \mathrm{M}$ \\
\hline Ga 13 & Slaughter house Plant & $28^{\circ} 37^{\prime} 11^{\prime \prime} \mathrm{N}$ & $77^{\circ} 19^{\prime} 31^{\prime \prime} \mathrm{E}$ & Borewell & $150 \mathrm{M}$ \\
\hline Ga 14 & Mullah colony & $28^{\circ} 37^{\prime} 16^{\prime \prime} \mathrm{N}$ & $77^{\circ} 19^{\prime} 37^{\prime \prime} \mathrm{E}$ & Borewell & $150 \mathrm{M}$ \\
\hline Ga 15 & Mullah colony & $28^{\circ} 37^{\prime} 12^{\prime \prime} \mathrm{N}$ & $77^{\circ} 19^{\prime} 45^{\prime \prime} \mathrm{E}$ & Borewell & $150 \mathrm{M}$ \\
\hline Ga 16 & Mullah colony Mosque & $28^{\circ} 37^{\prime} 8^{\prime \prime} \mathrm{N}$ & $77^{\circ} 19^{\prime} 38^{\prime \prime} \mathrm{E}$ & Borewell & $150 \mathrm{M}$ \\
\hline
\end{tabular}

et al. (2009) measured the highest concentrations of $\mathrm{Ca}$ and $\mathrm{Mg}$ with the values of $396.80 \mathrm{mg} / \mathrm{l}$ and $128.94 \mathrm{mg} / \mathrm{l}$ respectively, whereas the lowest $\mathrm{Ca}$ and $\mathrm{Mg}$ concentrations were measured with the value of $75.6 \mathrm{mg} /$ 1 and $29.28 \mathrm{mg} / \mathrm{l}$ respectively in Ibb landfill leachate.

High concentration of chloride ions results in objectionable taste in water. As per study, it was found that the chloride level in water samples was ranged between $60 \mathrm{mg} / \mathrm{l}-560 \mathrm{mg} / \mathrm{l}$ and it was recorded beyond the desirable limit is $250 \mathrm{mg} / \mathrm{l}$, at the Ga1, Ga2, Ga3, Ga4, Ga9, Ga10, Ga11, Ga12, Ga13 sampling sites (Table 2). Highest value of chloride $(560 \mathrm{mg} / \mathrm{l})$ was found at $\mathrm{Ga} 4$ sampling site, while the minimum value of chloride $(60$ $\mathrm{mg} / \mathrm{l}$ ) was found at the sampling site Ga5. Pathnaik et al. (2002) had observed that the chloride concentration was varied from $66 \mathrm{mg} / \mathrm{l}$ to $1250 \mathrm{mg} / \mathrm{l}$. Jhamnani and Singh (2009) reported that landfill leachate contain high concentration of chloride $(4,000 \mathrm{mg} / \mathrm{l})$, at municipal solid waste disposal site Bhalaswa in Delhi than the values recommended by the Central Pollution Control Board, Delhi, India. Rajkumar et al. (2010) studied on groundwater contamination due to municipal solid waste disposal in Erode District on the bank of Cauvery River in Tamil Nadu state and find that the chloride concentrations are to exceeded the permissible limits in four locations out of which three are very near to the MSW dump yards. Sulphate concentration of samples ranged from $43 \mathrm{mg} / \mathrm{l}-190 \mathrm{mg} / \mathrm{l}$ and it was found within the desirable limit $(200 \mathrm{mg} / \mathrm{l})$ of BIS at all the sampling sites (Table 2). Highest value of sulphate $(190 \mathrm{mg} / \mathrm{l})$ was found at the sampling site $\mathrm{Ga} 10$, while the minimum value of sulphate $(43 \mathrm{mg} / \mathrm{l})$ was found at the sampling site $\mathrm{Ga} 2$. Dhere et al. (2008) reported that unscientific disposal of solid waste plays an important role in the degradation of physico-chemical parameter of ground water such as BOD, COD, DO and sulphate. In the present study, it was found that all the parameters were directly affected due to various routine activities of the society. High concentration of nitrate causes Methemoglobinia (blue baby) in infants. Nitrate was recorded in the range of $0.03 \mathrm{mg} / \mathrm{l}-1.43 \mathrm{mg} / \mathrm{l}$ and it was found within the desirable limit (45 mg/l) of BIS at all the sampling sites (Table 2). Highest value of nitrate $(1.43 \mathrm{mg} / \mathrm{l})$ was found at the sampling site Ga12 while, the minimum value of nitrate $(0.03 \mathrm{mg} / \mathrm{l})$ was found at the sampling site Ga5. The concentration of nitrate was found in ground water sample up to $54 \mathrm{mg} / \mathrm{l}$ (Pandey et al., 2012).

Bureau of Indian Standards (BIS, 1991) has not prescribed any norms for phosphate in drinking water as phosphate is not considered as harmful constituent in drinking water. However, its presence accelerates the growth of algae. During the study period, phosphate concentrations in water samples were in the range of $0.23 \mathrm{mg} / \mathrm{l}-1.04 \mathrm{mg} / \mathrm{l}$. Highest value of phosphate $(1.04 \mathrm{mg} / \mathrm{l})$ was found at the sampling site $\mathrm{Ga} 4$ while, the minimum value of phosphate $(0.23 \mathrm{mg} / \mathrm{l})$ was found at the sampling site Ga16 (Table 2). Higher concentration of fluoride causes mottling of teeth. The fluoride concentrations in samples were in the range of $0.12 \mathrm{mg} / \mathrm{l}$ (minimum) - $0.72 \mathrm{mg} / \mathrm{l}$ (maximum) and it was recorded within the desirable limit $(1.00 \mathrm{mg} / \mathrm{l})$ of drinking water standards of BIS at all the sampling sites. Highest value of fluoride $(0.72 \mathrm{mg} / \mathrm{l})$ was found at the sampling 


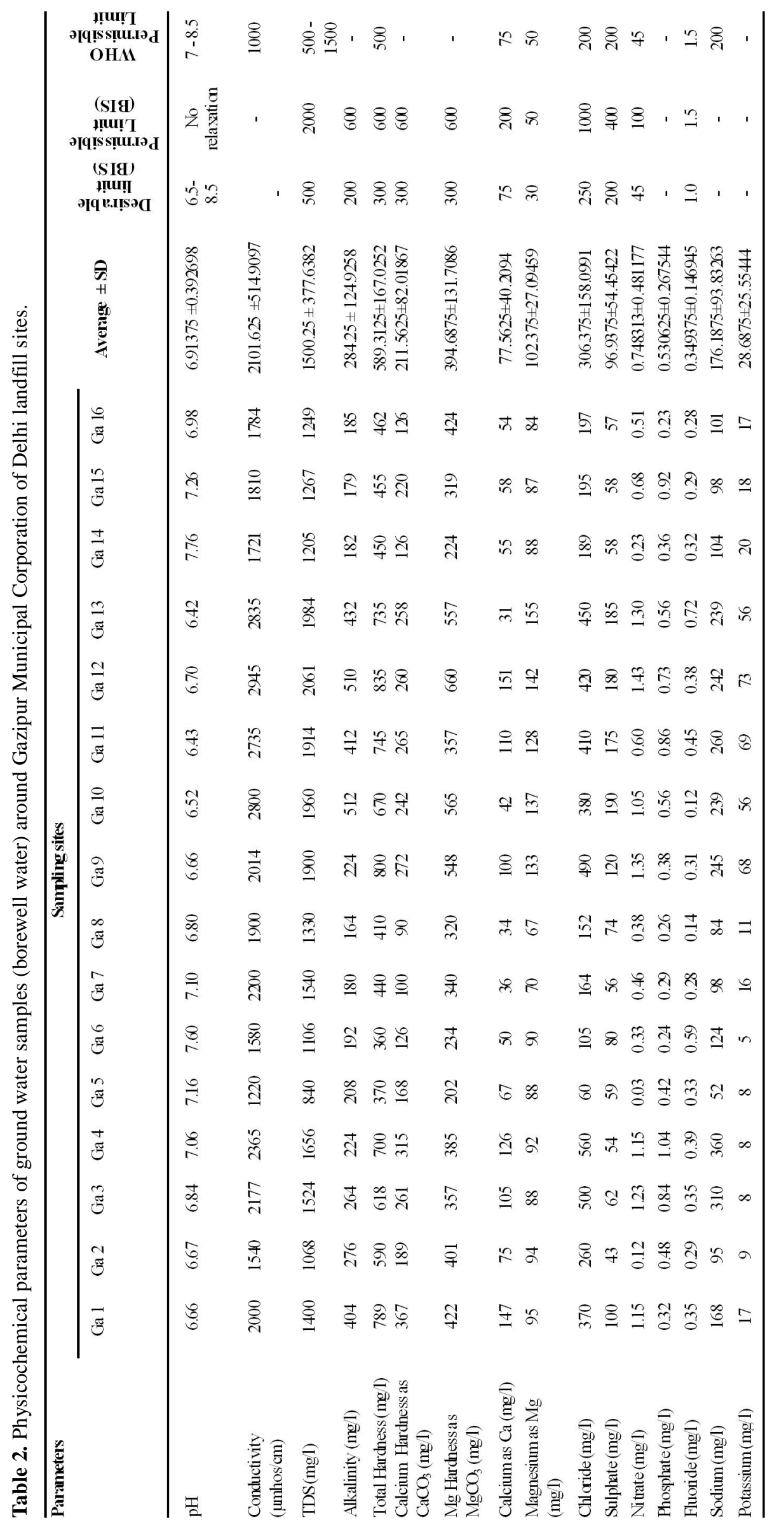


site Ga13 while, the minimum value of fluoride $(0.12 \mathrm{mg} / \mathrm{l})$ was found at the sampling site Ga10. According to Pandey et al. (2012), in the studied water samples near solid waste dumping site phosphate concentration showed under the permissible limit varied up to $0.05 \mathrm{mg} /$ 1 and the concentration of fluoride ranged from $0.01 \mathrm{mg} /$ 1 to $1.1 \mathrm{mg} / \mathrm{l}$.

BIS has not recommended any norm for sodium, whereas WHO prescribed its limit as $200 \mathrm{mg} / \mathrm{l}$ in potable water. Sodium is restricted in the diets of heart and kidney patients to avoid damages. High concentration of sodium will reduce the suitability of water for irrigation. Highest value of sodium $(360 \mathrm{mg} / \mathrm{l})$ was found at the sampling site Ga4 while, the minimum value of sodium $(52 \mathrm{mg} / \mathrm{l})$ was found at the sampling site Ga5 (Table 2). The occurrence of sodium above the WHO tolerance levels in wells closest to the landfill is an indication of possible leachate flow into groundwater (Adeolu et al. 2011). BIS also has not recommended any norm for potassium. Excessive intake of potassium may have laxative effect. As per the study, potassium concentrations in samples were found in the range of $5 \mathrm{mg} / \mathrm{l}$ (minimum) - $73 \mathrm{mg} / \mathrm{l}$ (maximum). Highest value of potassium $(73 \mathrm{mg} / \mathrm{l})$ was found at the sampling site Ga12 while, the minimum value of potassium ( $5 \mathrm{mg} / \mathrm{l}$ ) was found at the sampling site $\mathrm{Ga} 6$ (Table 2). As per the study conducted by Sabahi et al. (2009), potassium was found in low concentrations in natural waters since rocks that contain potassium are relatively resistance to weathering.

\section{Conclusion}

It was concluded that the Gazipur municipal dumping site, Delhi was found prone to the ground water contamination through leaching action. The concentration of various physico-chemical parameters viz. conductivity, total dissolved solids (TDS), alkalinity, total hardness, calcium, magnesium, chloride, sulphate, nitrate, phosphate, fluoride, sodium and potassium were recorded higher at all the Ga 1, Ga 2, Ga 3, Ga 4, Ga 9, Ga10, Ga 11, Ga 12 and Ga 13 sampling sites. Though the concentration of several other parameters in ground water is within permissible limits yet it is significant and is thought provoking as the ground water should have been free from any kind of contamination. Thus, there is a need of scientific management of the Gazipur dumping site to prevent ground water contamination and the regular monitoring of the ground water in and adjoining areas of landfill dumping site is also required.

\section{REFERENCES}

Adeolu, O.A., Ada, V.O., Gbenga, A.A. and Adebayo, A.O. (2011). Assessment of groundwater contamination by leachate near a municipal solid waste landfill. Africanj ournal of Environmental Science and Technology, 5(11): 933-940. Alewunmi, O. A., Ololade, I.A. and Adeleye, A. (2009). Effects of household wastes on surface and underground waters. International J ournal of Physical Sciences. 4(1): 22-29.

APHA (1998). Standard methods for the examination of water and waste water. 20th edition, Washington, D.C. American (pp-129) Public Health Association.

Aufleger, M. and Mett, M. (2011). Handshake across the Jordan: Water and Understanding. Ist edition: Innsbruck university press, Austria.

BIS (1991). Specifications for Drinking Water, IS: 10500:1991, Bureau of Indian Standards, New Delhi.

Bundela, P.S., Sharma, A., Pandey, A.K., Pandey, P. and Awasthi, A.K. (2012). Physicochemical analysis of ground water near municipal solid waste dumping sites in Jabalpur. International J ournal of plant, Animal and Environmental Sciences, 2(1): 217-222.

Dhere, M.A., Pawar, C.B., Pratapsingh, P.B. and Patil. D.A. (2008). Municipal solid waste disposal in Pune city- An analysis of air and groundwater pollution. Current Science, 95(6): 773-777.

Hadjibiros, K., Dermatas, D. and Laspidou, C.S. (2011). Municipal solid waste management and landfill site selection in Greece: irrationality versus efficiency. J ournal of G lobal NEST, 13(2): 150-161

Jain, C.K., Kumar, C.P. and Sharma, M.K. (2004). Irrigation water quality of Ghataprabha Command Area, Karnataka. Water Pollution, A.P.H. Publishing Corporation, New Delhi, 17: 145-158.

Jhamnani, B. and Singh, S.K. (2009). Ground water contamination due to Bhalaswa landfill Site in New Delhi. International J ournal of Civil and Environmental Engineering, 1(3): 121-125.

Kumar, N. and Sinha, D.K. (2010). Drinking water quality management through correlation studies among various physic- chemical parameters. International J ournal of Environmental Sciences, 1(2): 253-259.

Kumar, S. and Gaikwad, S. A. (2004). Municipal solid waste management in Indian urban centres: An approach for betterment in urban development debates in new millennium. Atlantic publishers and distributors, New Delhi: 101-111.

Longe, E.O. and Enekwechi, L.O. (2007). Investigation on potential groundwater impacts and influence of local hydrogeology on natural attenuation of leachate at a municipal landfill. Int. J. Environ. Sci. Technol., 4(1): 133140.

Moench, M. (1996). Groundwater policy: Issues and alternative in India. Colombo. Sri Lanka: International Irrigation Management Institute. X, 61p. (IIMI country paper, India. No.2).

Mor, S., Ravindra, K., Dahiya, R.P., and Chandra, A. (2006). Leachate characterization and assessment of groundwater pollution near municipal solid waste landfill site. Environmental M onitoring and Assessment, 118: 435-456.

Patnaik, K.N., Satyanarayana, S.V. \& Rout, S.P. (2002). A case study-water pollution from major industries in paradip area. Indian J . Environ. H ealth, 44(3): 203-211.

Rajkumar, N., Subramani, T. and Elango, L. (2010). Groundwater contamination due to municipal solid waste disposal - A GIS based study in erode city. International J ournal of Environmental Sciences, 1: 39-55.

Sabahi, E.A., Rahim, S.A., Zuhairi, W.Y.W. and Nozaily, F.A 
(2009). Assessment of groundwater pollution at municipal solid waste of Ibb landfill in Yemen. Bulletin of the Geological Society of Malaysia, 55: 21-26.

Sadek, S. and El-Fadel, M. (2000). The Normandy landfill: A Case Study in solid waste management. J ournal of Natural Resources and Life Sciences Education, 29: 155-161.

Shiddamallayya, N. and Pratima, M. (2008). Impact of domestic sewage on fresh water body. Journal of
Environmental Biology, 29(3): 303-308.

WHO (1971). International standards for drinking water. World Health Organisation, Geneva.

WHO (1983). Guidelines for drinking water quality. World Health Organisation, Geneva.

WHO (1997). Guideline for Drinking Water Quality, 2nd edition Volume 2, Health criteria and other supporting information, World Health Organization, Geneva, 9 pp. 